\title{
Internationalization in Education: The British Colonial Policies on Education in Nigeria 1882 - 1926
}

\author{
Dr. Folasade R. Sulaiman
}

\begin{abstract}
Department of Educational Foundations \& Instructional Technology, College of Applied Education \& Vocational Technology, Tai Solarin University of Education, Ijagun, Ogun State Email: folasade64@yahoo.com
\end{abstract}

Accepted: July 17, 2012 Published: August 10, 2012

Doi:10.5296/jsr.v3i2.2222 URL: http://dx.doi.org/10.5296/jsr.v3i2.2222

\begin{abstract}
British Colonial policies on education were formulated and implemented in Nigeria between 1882 and 1926, when it became apparent that the missionary education was not solving the education problems of the Nigerian natives.
\end{abstract}

Going by the records, western missionary education started in Nigeria in 1842, with the arrival of Thomas Birch Freeman, of the Methodist missionary society and Mr. and Mrs. De Graft of the church missionary society.

The initial objective of the missionary bodies to Nigeria was to carry out evangelical work i.e. preaching the gospel to the natives. Remarkable efforts were made by the various missionary bodies in building churches and schools which were all used for the purpose of evangelizing. The basic content of instruction in schools was reading and writing which were necessary for the understanding of the gospel.

However, these missionary schools were devoid of standard and uniform curricula, as each missionary body established schools to suit their specific needs. The practice of the missionary bodies in establishing and managing schools continued for about four decades after which, the colonial government according to Ajayi (1965) became critical of the small denominational schools that were not able to produce the clerks who were needed for the growing administration and expanding commercial enterprise in Nigeria.

This paper gives a historical appraisal of the formulation and implementation of British Colonial policies of education in Nigeria between 1882 and 1926. It also takes a look at the nature of such educational policies and critically evaluates the role played by the British colonial administration and the Christian missions. 
The paper would further assess the effects of the implantation of the existing British educational ordinances on Nigeria during the aforementioned period.

\section{Introduction}

Human nature and pre-occupation are basically characterized by movement. People move from one place to the other and from one role or situation to another for several reasons. One of the major reasons adduced to the constant shifting of roles or positions by men is the satisfaction of needs which according to Maslow (1954) are categorized in a hierarchical order. Man's movement usually follows some processes which could either be described as circular, linear, or deferred, depending on the purpose of such movement.

Human movement throughout the ages is one of the factors that have shaped and coloured the world today. Consequently, the millennium goals which virtually all countries in the world subscribe to, have been generally viewed by many scholars as Globalization or Internationalization. Globalization, according to Nwosu (2012), is a philosophy which synthesizes ideas, concerns and trends of the 20th to 21 st centuries all over the world such that a lot of issues raised on the platform of globalization and internationalization transcend the geographical confines of any nation or country to become a worldwide or international concern, e.g. the Millennium Development Goals (MDGs), The Education For All (EFA) to mention a few.

Generally, as a result of the breakthroughs in science and technology, global movement of humans has become a trend in which every living soul is involved in one way or the other. People watch events taking place over a thousand miles away, they listen to voices from over thousands of miles away and they travel several thousands of miles by air, on the water, etc. Education growth is the result of these trends where studies and research on ways of improving human learning and development are ongoing, even though continual or deferred growth depends on the societal needs and efforts put forth by the nations involved.

It is a common knowledge that most African countries have practiced traditional types of education according to their different culture, customs, usages and traditions from time immemorial, preparing their young ones for adulthood and the perpetuation of societal life and culture, until the Arabians and the Europeans set their feet on the African soil around the 14th and the 15th centuries respectively. In the case of the Arabians, trading and propagation of Islam were the main purposes of coming, while the Portuguese who reached the coastal regions of Africa in the $15^{\text {th }}$ century came in to trade. The slave trade of the 16th century, however, disturbed this trading relationship. In the 17th century, the British came to abolish slave trade and they were immediately followed by the Christian missionaries who came to propagate Christianity to the natives. The Christian missionaries' efforts in the propagation of Christianity were accompanied by western education which was meant to aid the reading of the bible and the singing of hymns for the converts. 
These evangelization efforts continued for several decades with different missionary bodies educating the natives according to their own interests and needs, i.e. the production of clergymen, interpreters, etc. On the other hand, the colonial governments concentrated on governing the country leaving education in the hands of the missionaries until it became obvious that the type of education offered by the missionaries could not serve the needs of the colonial masters and the newly evolving nations. The colonial government had to intervene in the education of the colonies by enacting education laws and edicts to guide the educational practices of the existing schools and their proprietors, and these formed the foundation upon which the educational systems of most African nations are built today.

\section{Theoretical Framework}

\subsection{Traditional Education}

The historical antecedent of education in Nigeria is based on traditional education with functionalism as a guiding principle. Like in any other parts of the world, the modern education curriculum can be described as a systemized and diversified version of the traditional or primitive education which was or used to be the culture or the way of life of people the world over. It can be categorically said that the theory and practice of education anywhere is a universal instrument of society's policy and as such modern day education can be seen as a deliberate evolution of education which still has its umbilical cord strongly tied to the norms, practices and aspirations of a particular group of people.

Traditional education has existed since time immemorial and been instrumental in solving societal existential challenges in areas like sustenance, governance, survival, etc. Children were raised, trained and put through rituals of passage to become full-fledged members of their societies; and they seamlessly fit in and continued with the works started by their forefathers. Every society, whether simple or complex, has its own system of upbringing and training of its young ones and members regarded as life-long education. This type of education has persisted and permeated the core of the human race giving it its nature, according to its geographical coloration.

However, the goals of traditional education and method of approach, according to Fafunwa (1974), may differ from place to place, nation to nation and people to people, and as such the Greek's idea of an educated man was one who was mentally and physically fit or balanced, the Romans on the other hand placed emphasis on oratorical and military training while in traditional Africa, the warrior, the hunter, the wise man who combined good character with a specific skill was adjudged to be a well educated and well integrated member of his community.

Invariably, the prehistoric African societies placed a great premium on functionalism as the main purpose of education which was also seen as means to an end. The traditional or indigenous education was meant for immediate induction of the young ones into the society 
and a preparation for complete adulthood. Fafunwa (1974) also stressed the fact that such traditional education emphasized social responsibility, job orientation, political participation, and spiritual and moral values. As a matter of fact, all the areas of the emphasis were core areas of human existence and endeavours which, if not well developed in an individual, would negatively impact him as well as the society he lives in. To this end, the values of traditional or indigenous education cannot be overemphasized and as such, the focus or the objectives deserve mentioning.

They are, according to Fafunwa (1974):

a. to develop the child's latent physical skills;

b. to develop character;

c. to inculcate respect for elders and those in position of authority;

d. to develop intellectual skills;

e. to acquire specific vocational training and to develop a healthy attitude towards honest labour;

f. to develop a sense of belonging and active participation in family and community affairs; and

g. to understand, appreciate and promote the cultural heritage of the community at large.

Osokoya (2002) submits that the objectives of the Nigerian traditional education were many and varied, but the ultimate goal was to produce an individual who was honest, respectful, skilled, cooperative and who could conform to the social order of the day. He goes further to say that each social institution had a role to play in providing both moral and practical teaching which would enable the younger ones to take up their rightful positions in the community. Children, according to him, were encouraged to explore their immediate environment, to observe as well as imitate the adults and to discover new grounds and knowledge. Furthermore, children and adolescents learnt the geography and history of their communities through storytelling and full involvement in the communal activities. They knew their local hills, valleys, rivers and plants. They knew when to expect rain and when to plant, when to hunt, fish and harvest. The elders used proverbs and riddles to develop intellect in the young ones. In all, huge emphasis was placed on complete human development. This was the major reason the traditional education was described as having a functional nature.

\subsection{Islamic Education}

Islamic education which was introduced around the 14th century in the northern part of Nigeria was also going on alongside the traditional education. It was introduced as a means of spreading Islam, and converts were made to read and write the Arabic language in order to understand the Islamic religion. The people learnt about Islamic law, Islamic poetry, grammar and literature of Islam. The Islamic religion also suited the people as it served their needs in the same manner traditional education served the needs of the whole African communities. Islamic education was fully entrenched in the northern part of the country, long 
before the arrival of the western missionaries as evidently presented by Osokoya (1995), that about 19,073 Qur'anic schools were existing with an enrolment of 143,312 students as at 1913, as against 41 western education schools in Nigeria.

In the views of Ijaduola (1998), Islamic education was basically an orientation towards social stability hence, there was a great need to obey the Holy Qur'an which was believed to be the words of Allah given through Prophet Mohammed. Islamic education can be rightly described as a way of life of the people who subscribed to it. It spread through the northern part of Nigeria to the southern and eastern parts. Islamic education rests solely upon the Qur'an and is divided into different categories according to Adenokun (2004). The major source of information and the major curriculum of Islamic education is the Qur'an as well as the Hadith which contains the prophetic traditions. The Islamic law (fiqh) and the canon law (sharia) were all derived from the Qur'an and the hadith. The Islamic school has no age barrier as a student can join the level his intellect allows him or her.

Just like the traditional education which had a clear cut objective, the Islamic education also has its aims and objectives, some of which are listed by Ijaduola (1998) as:

a. balancing the growth of total personality of man through the training of his mind, intellect, rational self and bodily senses. Faith is important so that an emotional attachment to Islam is established through the learning of the Qur'an and the Sunnah;

b. creating of a good and righteous man who will worship Allah in truth, build up the structure of his earthly life according to sharia law and employing it to serve his faith;

c. promoting in man the creative impulse to rule himself and the universe as a true servant of Allah;

d. producing men who are totally committed to the ideals of Islamic ethics and preparing them for a life of purity and sincerity;

e. instilling piety and encouraging self purification as a means of assisting man to realize the deep mysteries of the universe.

Islamic education in the opinion of Adenokun (2004) has survived tremendously, and rather than being abandoned after the introduction of western education, it has been integrated into formal education and still plays a role in the life and education of many countries along the coast of West Africa. Buttressing Adenokun's (2004) view, the Federal Government of Nigeria (2004) says efforts shall be made by State governments to integrate suitable Koranic and Islamiya schools within the formal education system (NPE, Section 3,11).

The Arabic language used for the propagation of Islamic education is still very much alive and relevant among the muslims. The survival of Islamic education can also be traced to the fact that graduates can become employed immediately as proprietors, editors, chroniclers, local judges, preachers, etc., by virtue of the type of education they received during training.

Traditional and Islamic educations have been observed to have limitations when viewed along the line of the modern day education. Such limitations include: 


\section{Macrothink}

a. Narrow interest: Islamic education is limited in view and may not allow recipients to venture into other fields of knowledge. In the same vein, the traditional education is geographically bound, i.e. it is limited to the community of the recipient - not universal in nature;

b. Lack of proper documentation: The Islamic education has no prescribed curriculum. The holy Qur'an and the tradition of the Prophet are the only available textual material used, while traditional education uses oral tradition and storytelling as the major tools of teaching the recipients;

c. Indoctrination: Islamic education is a form of indoctrination, it closes the minds of the learners to reason, as fear is mostly instilled in order to get complete attention, obeisance and obedience;

d. Islamic education uses corporal punishment as a basic tool.

\section{The Development of Modern Education}

\subsection{Introduction}

The global currents of the 15th century initiated European contact with the indigenous societies. The Nigerian entity was not yet evolved even though social, cultural and political units coexisted and maintained economics, commercial and social relationships among themselves. Historically, the first set of Europeans who made contact with Nigeria were the Portuguese who came in order to establish trading relationship with the natives, and along the line established schools and churches to promote trading relationships. They maintained a trading relationship and used the Roman Catholic Church creed to evangelize as well as give modern education to the natives for almost a century, before the trans-Atlantic slave trade which ravaged the African continent for almost three hundred years came to wipe away all their efforts. The abolition of the slave trade by the British government opened yet another opportunity of trading relationship with Africa and Nigeria in particular. The freed slaves were settled in Freetown, Sierra Leone and engaged in trading activities along the coastal regions which made some of them to trace their route back to their homes before enslavement. The reunion led to the invitation of the missionaries to come for evangelical work in their towns in order to stop their kin from the practice of worshipping idols and other traditional activities deemed unreasonable. Such invitation led to the arrival of the Weslayan missionary body at Badagry in 1842, and several other missions followed suit and spread themselves to all corners of the country. These missionary bodies built churches and schools at their arrival at any station, for preaching the gospel and educating the natives in the modern method of education, while the colonial government governed the colonies exclusively. Decisive efforts were later made by the colonial government to participate in the education of the natives, by enacting education laws to control the activities of the missionaries especially in their school system.

\subsection{The Initial Attempt at Modern Education}


In the latter part of the $15^{\text {th }}$ century, the Portuguese arrived on the soil of Nigeria through the Gulf of Guinea which bordered the coastal region of South East and South South Nigeria. This expedition was mainly for economic and commercial purposes, but it was not too successful as there was a strong language barrier. The Portuguese did not lose hope as they were determined to make their impact felt on the African soil. This determination brought about the introduction of the Christian faith to their trading partners and customers. In the early $16^{\text {th }}$ century, precisely in 1515 , the Portuguese built a church and a school in the palace of the Oba of Benin for his children and the children of his chiefs. The Roman Catholic mission had been fully entrenched in Benin and other parts of Nigeria because as at 1571, there were churches and schools as well as several trading posts in Lagos, Benin and Brass. Another strong effort of the Portuguese in spreading Christianity was the building of a seminary on the island of Sao Tome which was off the Nigerian coast.

The seminary, according to Osokoya (2002), was mainly for the training of the Africans as priests and teachers, to manage the churches and schools that were already founded. Sadly enough however, the trans-Atlantic slave trade which began in the $16^{\text {th }}$ century and lasted for about three centuries wiped out all the educational efforts of the Portuguese in Nigeria.

\subsection{The Second Attempt at Modern Education in Nigeria}

Slave trade became outlawed as the British government abolished it in 1833, in what was then known as the British Empire. Freetown in Sierra Leone was acquired as a colony where the liberated African slaves were settled. Some of the freed slaves started trading along the coastal regions and found their ways back to their roots in Abeokuta, Oyo, Lagos, Ibadan, Badagry, etc., in Nigeria. Obviously the freed slaves while they were still enslaved had been introduced to Christianity in the countries of their enslavement, and this later became the foundation of the efforts they made to invite the missionary bodies to their country, Nigeria, to come and preach the gospel to their kin, in order for them to stop their crude ways of living which then included making human sacrifice and the like.

The Weslayan Methodist Society was the first missionary body to honour such invitation with the arrival of Thomas Birch Freeman and Mr. and Mrs. De-Graft to Badagry on the $24^{\text {th }}$ of September 1842. The first school was opened shortly after their arrival. The church missionary society also sent a group of people headed by Mr. Henry Townsend to Abeokuta for evangelism and education, but did not get to Abeokuta until 1846 and they immediately built two schools, one for the boys and one for the girls. These two missionary bodies played a fundamental role in the planting and nurturing of both Christianity and western Christian education in Nigeria (Adenokun, 2004).

The Roman Catholic Mission impact was soon felt with the arrival of Padre Antonio in Lagos, where he started evangelical work in earnest with the building of a school in 1868 . With the efforts of the Portuguese of the late $15^{\text {th }}$ century and the early $16^{\text {th }}$ century still surviving, the Roman Catholic Church did not have much problem in resuscitating the creed. 
The Presbyterian mission arrived at Calabar in 1846 and made their impact felt by opening their station. The Southern Baptist Convention started their own evangelical work by opening a school in Ijaye in 1853, they continued to Ogbomoso and Lagos where they opened a school each in 1855. In this same spirit of evangelism and education, the Niger mission headed by Rev. Samuel Ajayi Crowther and Rev. J. C. Taylor established schools in 1857 at Gbede and Onitsha, while in 1864 another school was opened at Idda then in Akassa and Bonny. The missionary bodies continued to wax stronger in their evangelical work by moving inwards into Nigerian towns and regions, spreading Christianity by building schools and churches. They all followed the same pattern i.e. building churches and establishing schools which were mainly for the production of preachers, catechists, teachers and clerks for spreading evangelical work.

However, the missionary schools started facing a lot of challenges as they grew in number; they no longer served the evolving needs of the native peoples and societies, as the content of instruction was too limited to produce the kind of people needed for the work of ruling or governing the country, as well as developing technologically; hence the need for the colonial government to intervene in the education of the people, by establishing ordinances and education laws, to control the activities of proprietors of schools either government owned or missionary.

\subsection{The Colonial Government Education}

The major interest of the colonial government was political, and such that by the year 1851 there was already a strong political alliance between the British government and Lagos, and by 1861, Lagos had already become a British colony. The education of the people was solely in the hands of the missionaries even after the colonization. However, the colonial government made an impact on education in the year 1872, by giving a paltry sum of money to the three most prominent missionary bodies, to aid their education activities in Lagos (The Church Missionary Society - CMS, the Weslayan Methodist and the Catholic Mission).

That first move marked the beginning of grants-in-aid to education which according to Osokoya (2002), formed the major educational financing policy of the colonial government. The grant was increased in 1877 and remained like that until 1882, when the colonial government felt that the entire running of the education system should not be left in the hands of the missionaries alone. Such decision thus led to the laying of the conditions for grants-in-aid; consequently the education ordinances were established.

\subsection{The Colonial Education Ordinances}

The education ordinances that were passed on the education system during the colonial rule significantly gave the control of education to the colonial government, who had hitherto left 
the education in the hand of the missionary bodies for close to a century, until it no longer served the needs of the local people and the Government.

The first of such ordinances was the 1882 ordinance, which was meant to address the imbalance in the education system, and to establish a substantial amount of control on the education activities of the missionary bodies.

The ordinance provided for:

- the constitution of a General Board of Education; Local Board of Education;

- classification of schools into government schools and assisted schools;

- the freedom of parents to choose the religious instruction of their children;

- school buildings and teachers' salaries to be financed by the grants;

- appointment of inspector of schools for all British West Africa;

- grants to be made available to industrial schools;

- defining the school curriculum to include reading, writing, English Language, Arithmetic and Needlework for girls; and

- admission of pauper children into government and assisted schools.

The ordinance however did not achieve much of its goals as they were too narrow, and closely imitated the English Elementary Education Act of 1870, which according to Osokoya (2002), aimed at satisfying the needs of the English child at that time. And since environmental factors matter a lot in the formulation and implementation of education policy, there was a need to review the 1882 education ordinance to make it environment relevant.

The 1887 education ordinance was enacted to correct the first one which failed to solve the education problem of the colonies. The second ordinance could be seen as the first effective attempt by the government to promote education and control the rate at which the missionary bodies expanded their own type of education. The 1887 education ordinance provided for the:

- constitution of a Board of Education which was made up of the Governor who was the chairman, members of the Legislative Council, four nominees of the governor and the inspector of schools;

- appointment of an inspector of schools and a sub-inspector of schools and other education officers;

- extension of grants-in-aids to teacher training colleges;

- empowerment of the governor to open up and maintain schools;

- assessment of the conditions of grants-in-aids to infant schools, primary schools, secondary schools and industrial schools, based partly on the subjects taught as well as the degree of excellence in the schools and safeguarding of religious and racial freedom;

- issuance of certificate to teachers;

- admission of pauper and alien children into schools;

- establishing of scholarships for secondary and technical education. 
In appraising the 1887 education ordinance, Adenokun (2004) observed that Rev. Henry Carr pursued the ordinance with vigour and his team went ahead to start off government schools to demonstrate examples and precepts. A certain standard was to be met to satisfy the conditions of qualifying for grants-in-aid; the Christian missions were therefore forced to improve the quality of their existing schools. He further submitted that such high standards set by the government discouraged further expansion of the educational system as the missionary bodies found it difficult to meet up. A gap was eventually created between the "assisted" and the "unassisted" schools which also led to the establishment of illegal schools. Henry Carr who was the sub-inspector of schools for the Lagos colony and Southern protectorate in 1889 , advocated strongly for government control of schools and greater financial support.

The amalgamation of the colony and the Protectorate of the South with the Northern Nigeria in 1914 and the appointment of Lord Frederick Lugard as the Governor-General of Nigeria, brought about another shift in the education system as the Governor-General was dissatisfied with the education system both in the Southern and the Northern parts of the country. He set up Boards of Education to look into the different areas of the country. The ordinance and code that later emanated were five and included:

i. training on the formation of character and habits of discipline;

ii. cooperation between government and missions;

iii. giving rural as well as urban education;

iv. increasing the number of literates in Nigeria to meet the increasing demands for clerks and similar officials;

v. government control over all schools including non-assisted schools.

The ordinance major achievement according to Osokoya (2002), were its ability to cover the whole of the country, the increased financial participation of government and the missions, and a measure of government control over education in general. Other remarkable achievements included the stipulation of the age limit of people in the infant classes as well as in the elementary school system. The code also granted religious instruction as an examinable subject which was very much welcomed by the missionary bodies.

A memorandum on Education Policy in British Tropical Africa was dispatched to the colonies in 1925 as a basis for the British Colonial education Policy. The ordinance was seen as a landmark in the development of education in Nigeria, and an outcome of the recommendations of the 1920 Phelps-Stoke Commission on Education in Africa whose terms of reference were:

a. to inquire into the existing educational work in each of the areas to be studied;

b. to investigate the educational needs of the people in their religious, social, hygiene and economic conditions;

c. to ascertain the extent to which these needs were being met; and

d. to make available in full the result of the study. 
The report of this commission, according to Osokoya (2002) and Fabunmi (2005) geared the British colonial administration to demonstrate increased interest in African education, which led to the issuance of the first educational policy in 1925.

To put into effect the education policy of 1925, the Governor, Sir Hugh Clifford identified the poor quality of education and the growth of substandard schools as the two major problems of the education system. Consequently he proposed for financial provision for education and control of educational development. And upon turning the education situation around in the colony and the southern provinces, an educational ordinance was enacted in 1926 in which:

a. the registration of teachers became a condition for teaching in any school in the colony and southern provinces;

b. new schools would only be opened after approval by the Director of Schools Education and the Board of Education;

c. closing of the schools operated in a manner detrimental to the interest of the community where they were sited;

d. defining the functions and duties of supervisors;

e. strengthening of the Board of Education to consist of the Director; the deputy Director of Education, the Assistant Director, ten representatives of the missions and other educational agencies, and redefining the board's functions to include advice to the government on educational matters;

f. regulating minimum pay for teachers in the assisted schools. This was a provision in respect of the ordinance, whose main objective was to curb the development of substandard schools which were growing almost uncontrollably.

The provision of quality teachers and improving the conditions of teachers were all part of the ordinance provisions. The ordinance also provided schools with experienced leadership and guidance, created conducive atmosphere for cooperation between missions, other voluntary agencies and local communities, and supplying the needs of individuals and communities in Nigeria.

\section{Internationalization in Education: The Nigerian Experience}

The western education in Nigeria which was purportedly championed by the missionary bodies, would not have been possible if the natives were not in support of it, and had not agreed to participate in it; as has been rightly summed up by Iwunna (2011), the supply of missionary education to Igbo towns and villages involved a chain of participants, which suggests that if the project did not receive any welcome, or had been left or abandoned in the hands of the missionary bodies, there would have been less progress and spread of education recorded. The view expressed above indicates the support and encouragement western education received from the Nigerians, who showed their zeal to experience other types of education different from the one (traditional/indigenous) they were used to. Supporting this 
opinion, Dubois et al (2006) submit that “... regardless of whether one system is considered better or worse than another, experiencing a different way of education can often be considered to be the most important enriching element of an international learning experience".

Reiterating the support of the natives for modern education, Omolewa (2006), Fafunwa (1984), Njoku, Ogbonna and Anorue (2005) opined that the establishment of mission schools in Igbo land as well as all over Nigeria, involved the participation of several contact points, whose roles influenced the spread of western education, in which case mission schools did not emerge overnight as time, financial resources as well as material and logistic inputs were committed by the numerous agents of education.

Arguably, the British colonial governments gave their full support to the missionary bodies in the pursuit of their objectives i.e. evangelical work through the establishment of schools and building their churches, but the deeper reality is one of multiple connections, Mulgan (1998).

Trading relationships continued to wax stronger since the workforce has been introduced to the new ways of doing things. Raw materials for exportation to home countries of the colonials improved in quality and quantity with the introduction of western type of education, more than through the missionary activities alone. The contribution of globalization to economic growth in developing and developed countries is experienced in the application of the improved ways of doing things in all the endeavours of man, thereby using education to reduce the barriers to international trade. In supporting the use of education in this manner, Moylan (2005) submits that globalization may contribute to economic growth in developed and developing countries through increased specialization, and the principle of comparative advantage. Also observed is the strong increasing global relationship of culture and transnational circulation of ideas, languages and practices, Bhagwati (2004). Supporting the above is the tone of the curricula in schools which are evolving with diverse phases of dynamism to widen the scope of learners and citizens of nations.

The relationship between education and development has obviously been fully established to the extent that education is now internationally accepted as a key index of development, and it is in recognition of this importance that governments all over the world have made commitments in their countries' educational policies, for their citizens to have access to education (Odukoya, 2009). Education has transcended national borders in centuries past, as earlier civilizations have influenced nations across the globe. And the submission of Imam (2002) succinctly puts it: “...as regards education in Nigeria, colonialism and post-colonialism are the conceptual frameworks that make visible, the legacy of the British colonial education policy". The close alignment of Nigeria education policy's philosophy of the right of all people to education; the material and cultural well-being, changes in the way people think, and the way they behave are a reflection of the dynamic process of nation building that is constantly being modified by new policy demands. Generally, education is viewed in terms of a change in behavior since the recipient should have acquired a new state 
of having, a new state of being, and a new way of doing things. Evidently, there is an observable relationship between education and national development, which continues in Africa and is shown in the constant review of their educational policies to meet the needs of the people and their environment. This view is supported by Woolman (2001), when he says that since education is an agent of cultural transmission as well as change, it should also reflect the dynamic process of nation building that is continually being modified by new conditions.

Consequent upon the above submission, education during the pre-Independence era and post-Independence era was constantly reviewed to reflect the changes that have occurred, as well as those envisaged over time. The issuance of the 1882 educational ordinance which indicated the beginning of the participation of the colonial government in the education of the natives, was reviewed in 1887 to effect new changes that have occurred in the education system.

It was further reviewed and changed in 1889 to accommodate yet another phase of development, while in 1916, an ordinance that covered the whole country in the matters of education i.e. the southern and the northern parts, as well as the colony was established. The 1926 ordinance which came as result of the report of the Phelps-Stoke Commission was found to be more encompassing, because it stipulated the need for education to address the needs of the individual in relation to his environment. Thus, the 1926 educational ordinance laid the foundation for education to be suited to local needs, so that recipients can be fully absorbed into their local environment and contribute their own quota to the growth and development of their nation. The ordinance also encouraged the study of the language of the immediate environment and recommended education for girls and women, as it is believed that everybody has a contribution to make towards the growth and development of the country. The ordinance also specified the duties of supervisors and the inspectors of the mission schools, all of which are found in the duties of the ministry of education, zonal education offices, etc. Schools also had to get approval from the Director of the Board of Education before being opened.

Actually, the changing concept of the educational ordinances as a result of their being revised portrays the dynamic nature of education, i.e. an education that is meant to solve societal problems; it is also regarded as one that is meant to change people's lives, as the society keeps evolving, to accommodate the global changing experience resulting from the interrelationship in the world of humans.

Internationalization did bring about improvements which include the opportunities for new and improved way of life, as a result of the breakthroughs in science and technology. Just as has been observed that the balance between knowledge and resources has shifted so far towards the former, and that knowledge has become perhaps the most important factor determining the standard of living i.e. more than land, tools, and labour. Today's most technologically advanced economies are truly knowledge-based (World Bank, 1998). As 
much as these technological or scientific breakthroughs open doors of great opportunities for people, some countries benefit maximally while others do not.

Using Nigerian education as an example where the curricula of schools during the colonial era was not in balance with the needs and aspirations of the people for decades, a platform for a 'knowledge economy' was not really created. This has resulted in the more developed economies benefiting from the influx of brilliant Nigerian minds in search of greener pastures to actualize their dreams. The situation was termed "Brain Drain in Africa" by a team of researchers at the Centre for Global Studies, University of Illinois, who submit that opportunities in rich countries attract skilled workers from poor or developing countries.

There is no gainsaying though, that the internationalization of education did come along with challenges, which sometimes present themselves as hindrances to the achievement of some educational goals, even globally. Like the misuse of information or tools that create a negative perception of innovation; the global cultural exchange which may be a kind of disadvantage to the Nigerian nation, as the youths do not want to listen to local songs anymore, causing a loss of values; traditional performers are no longer really appreciated as in the past. This has a negative effect on the development of individuals with national consciousness and a sense of belonging, which is one of the goals of education in Nigeria as contained in the National Policy on Education document (FRN, 2004).

It seems most of the sources of information an individual needs to understand his environment, in order to attune himself to his cultural background, have been cut off from him in the process of receiving western type of education. Closely related to this observation is the language of globalization which has eroded the use of the native languages in the homes, thereby creating alienated individuals right on their own soil. Unfortunately however, this language of globalization is not well used because it is not well-taught in schools, thereby creating confusion between the local and the English cultures. Aligned to this is the use of mobile telephone technology which encourages the use of abbreviations in sending text messages with the resultant effect of failure in the knowledge of the proper use of English language, at formal occasions such as writing examinations or attending interviews for seeking job placements. A lot of university graduates daily roam the streets of cities seeking office appointment without much luck, as a result of the content of instruction in schools not matching the needs of the job market; and this is traceable to the effect of the colonial days' curricula which still form the basis for even the millennium era curricula, as most of the innovations in the education system are only paper work with little physical transformation as was also inherent in the colonial education.

In supporting the inadequate education policies of colonialism, Duke II (2010) submits that the colonial government deliberately abandoned the education sector to the religious missions and private individuals, with no clear or systematic policy in place. The result was that given their limited resources, the missionaries were only able to provide functional grammar schools that turned out a mass of people literate enough to sustain employment in clerical, 
teaching or instructional jobs, but with insufficient managerial skills or technical competences or capacity. The educated workforce was therefore ill-equipped with the depth of rigorous scholarly or academic skills required for developing a body of organized principles and theories that facilitate the management of institutions and organizations.

In the same vein, the report of the National Commissions for Museums and Monuments (1986) shows that, at the core of the education policy of the colonialists, was the objective of producing a literate, but junior clerical and middle level manpower cadre, fit to work at government offices, trading companies and sub-tertiary educational institutions. This meant that the authorities spent limited resources on the creation and development of educational institutions that would normally produce a workforce equipped with high level technical, innovative and managerial skills. Specifically, the policy emphasis was on primary or elementary school education. Grammar and secondary schools were few and far in-between. Technical or industrial schools were even fewer, with about 900 primary schools with a pupil population of 40,000 in Calabar province as at 1931, and only three technical schools and two secondary schools in existence. There were no tertiary institutions whatsoever within the province during the period assessed.

The policies of the colonial government which were based on exploitation extended even after their exit on the Nigerian soil, as the legacy they left behind was translated into almost every transaction made in Nigeria between investors and the Nigerians. As observed by Klein (2001), multinationals can impact upon communities in very diverse places by establishing or contracting operations (productions, service and sales) in countries and regions where they can exploit cheaper labour and resources. This is evident in the cases of international schools like Turkish, American, French schools, etc., which use Nigerian teachers without remunerating them equally with their foreign counterparts. Also observed are some universities from the western or developed countries bombarding Nigeria with their educational programmes, right on the Nigerian soil, and making little of the Nigerian education system, because the multinational companies do not want to employ graduates from Nigerian universities, mostly because of their perceived limited content of instruction which was actually the making of the colonial governments, and some politicians without focus, resulting in the decline of the standard of education in the country.

Evident also is another negative effect of internationalization of education, where the youths no longer have interest in reading in the libraries, as a result of the computer/internet which unfortunately, they use for the wrong reasons. Instead of equipping themselves with the type of information that will develop their minds positively, they engage themselves in the negative use of the internet, since the government no longer has time for the youths, as all the recreation places have been sold out to investors who build companies that do not employ Nigerian labour or graduates.

Lifelong education which used to be the basis of youths' education, has taken different perspectives which do not lead to the achievement of any positive goals for the youths or the 
actualization of their dreams. The youths are actually at the receiving end of most of the negative impacts of the internationalization of education, as well as the globalization trends which show in the low quality of the life they now live.

Ironically, the slogan of most countries on children is that they are the "leaders of tomorrow"; but with the poor educational legacy of the past and present leaders, will internationalization and globalization of education yield the right type of individuals and the dividends that will effect the changes needed to salvage the educational system and produce good "leaders of tomorrow"?

\section{Conclusion}

The modern education of Nigerians which started as an evangelical move by the missionaries as well as a trading relationship by the colonial masters, changed according to the needs of the proprietors, through all the decades following its establishment, till independence as a sovereign country. Unfortunately, the legacy left in the education system by the colonial government still influence the practice of education in Nigeria today, as education has not really been able to solve the problems the society carried from its inception to date. Granted, the internationalization of education opened vistas of opportunities for the citizens which sadly enough, were not properly harnessed or channeled for the actual purpose they were meant to serve.

The internationalization of education would have been the greatest opportunity offered to Nigerians to turn around their inadequate situation into a better and promising one for themselves, and for generations of Nigerians yet unborn.

\section{Recommendations}

After reflecting on the education system in Nigeria, recommendations such as the reorientation of the Nigerian leaders would be highly appropriate here. The idea of putting round pegs in square holes is not conducive to achieving any positive goals. It should be discouraged and the goals of education should be clearly spelt out and should be pursued by the right type of leadership, with the right type of orientation towards what the country actually needs to meet up with the millennium goals.

A roundtable discussion should be organized where stakeholders address the pressing needs of the country without sentiments, and pursuance of education goals should be carried out honestly by conscientious leaders, for citizens to have the opportunity to actualize their dreams in the wake of internationalization and globalization. 


\section{References}

Adenokun, A. A. (2004). Functional Approach to History of Education in Nigeria. Ijebu-Ode: Lucky Odoni (Nigeria) Enterprises.

Ajayi, K. (1987). "Problems and Prospects of Curriculum Development in Nigeria" in Ajayi, K. and Ajayi, T. (Eds.) New Perspective in Nigeria Education. Ibadan: Vantage Publishers.

Bhagwati, J. (2004). In Defense of Globalization. Oxford, New York: Oxford University Press

Dubois, H.F.W.; Padovana, G. \& Stew, G. (2006). Improving International Nurse Training: An American-Italian Case Study. International Nursing Review, 53(2), 110 - 116.

Duke II, J. (2010). The Impact of Colonization on the Development of Management in Nigeria. International Journal of Business and Management, www.ccsenet.org/ijbm, Vol. $5(8)$.

Fabunmi, M. (2005). Historical Analysis of Educational Policy Formulation in Nigeria: Implications for Education Planning and Policy. International Journal of African \& African American Studies. July, Vol. IV(2).

Fafunwa, A. B. (1967). New Perspective in African Education. Lagos: Macmillan and Co.

Fafunwa, A. B. (1969). A Philosophy for Nigerian Education in Adaralegbe, A. (ed.) Philosophy for Nigerian Curriculum. Report of the National Curriculum Conference.

Fafunwa, A. B. (1984). Education in the Developing Countries with particular reference to Africa. Paper presented at the International Conference of Comparative Education for Nigeria. Lagos: CESAC.

Federal Republic of Nigeria (2004). National Policy on Education. Lagos: Federal Government Press.

Ijaduola, K. O. (1998). Education in Nigeria: An Historical Perspective, Ijebu-Ode, Lucky Odoni (Nig.) Enterprises.

Imam, H. (2012). Educational Policy in Nigeria from the Colonial Era to the Post-Independence Period. Italian Journal of Education, 1. 


\section{Macrothink}

Journal of Sociological Research

ISSN 1948-5468

2012, Vol. 3, No. 2

Iwunna, P. (2011). The Agents of Colonial Education in the Context of the Catholic Mission Primary School Educational Activities in Igboland, Southeast Nigeria (1925 - 1960). African Journal of Historical Sciences in Education, April, Vol. 7(1), 293 - 311.

Klein, L. (2001). Globalization and the Impact of Multinationals on Local Communities.

Maslow, A. H. (1954). Motivation and Personality. NY: Haper.

Mulgan, G. (1998). Connexity: Responsibility, Freedom, Business and Power in the New Century (Revised Edition)/. London: Viking.

National Commission for Museums and Monuments (1986). The Story of Old Calabar. Calabar: Old Residency.

Njoku, A. P. C.; Ogbonna, H. \& Anorue, M. (Eds) (2005). Maria Assumpta Cathedral Nigeria Silver Jubilee. Souvenir of Dedication, pp. $1-32$.

Nwosu, D., Sulaiman, F. R. \& Alege, B. A. (2012). NCCE as a Pacesetter in Quality Assurance, Curriculum Innovation, Developmentalism and Holistic Globalism in Nigeria. Paper presented at the Conference of AFTRA Teaching and Learning in Africa, Cotonou, Republic of Benin.

Odukoya, D. (2009). Formulation and Implementation of Educational Policies in Nigeria. Educational Research Network for West and Central Africa (ERNCAWA), www.slideshare.net

Omolewa, M. (2006). Educating the "Native": A Study of the Education Adaptation Strategy in British Colonial Africa, 1910 - 1936. The Journal of African American History, 91(3), 237 $-287$.

Osokoya, I. O. (2002). History and Policy of Nigerian Education in World Perspective. Ibadan: AMD Publishers.

Woolman, D. C. (2001). Educational Reconstruction and Post-Colonial Curriculum Development. A Comparative Study of Four African Countries. International Educational Journal, 2(5), 27 - 46.

World Bank Research (2002). 'Globalization, Growth and Poverty: Building an Inclusive World Economy'. The World Bank Group, http://econ.worldbank.org/prr/subpage.php?sp=2477 